\title{
MENGGUNAKAN PERSPEKTIF POST- DEVELOPMENTALISME: BERNYANYI DI PENDIDIKAN ANAK USIA DINI
}

\section{A POST-DEVELOPMENTALISM PERSPECTIVE: SINGING IN EARLY CHILDREN'S EDUCATION}

\author{
Suci Ramdaeni*1 \\ IAIN Syekh Nurjati Cirebon
}

email: suciramdaeni@syekhnurjati.ac.id

• Received: 29 April 2021 •Accepted: 3 Mei 2021 •Published online: 1 Juni 2021

\begin{abstract}
Abstrak:
Penelitian ini bertujuan untuk mengeksplorasi konstruksi gender di Pendidikan Anak Usia dini. Melalui perspective post-developmentalisme penelitian ini membongkar bagaimana biner maskulin dan feminim memperkuat ketidaksetaraan di PAUD. Penelitian ini menggunakan metode penelitian metaanalisis yang mengintegrasikan penelitian terdahulu melalui perspective post developmentalisme. Hasil temuan penelitian ini menunjukan bahwa anak seringkali memperkuat ketidaksetaraan melalui pemahaman streotipe gender, pemilihan jenis lagu, dan pemilihan instrument lagu yang di konstruksikan di PAUD. Harapannya penelitian ini menjadi sebuah refleksi kepada guru dan orang dewasa untuk lebih sensitive gender. Sehingga anak laki-laki dan anak perempuan mendapatkan stimulasi dan pengalaman yang sama dalam bernyanyi di PAUD.
\end{abstract}

Kata Kunci: Post-developmentalisme, Gender, Pendidikan anak usia dini

\begin{abstract}
:
This study aims to explore gender constructs in early childhood education. Through a postdevelopmentalism perspective, this research uncovers how masculine and feminine binaries reinforce inequality in PAUD. This study uses a meta-analysis research method that integrates previous research through a post-developmentalism perspective. The findings of this study indicate that children often reinforce inequality through understanding gender stereotypes, choosing the type of song, and selecting the song instrument that is constructed in early childhood education. It is hoped that this research will become a reflection for teachers and adults to be more gender sensitive. So that boys and girls get the same stimulation and experience in singing in PAUD.in the form of stimulation and the same experience in singing to boys and girls.
\end{abstract}

Keywords: Post-developmentalism, Gender, Early childhood education

\footnotetext{
*Corresponding Author, Email: suciramdaeni@syekhnurjati.ac.id
} 


\section{A. PENDAHULUAN}

Pendidikan anak usia dini merupakan pendidikan dasar dimana anak-anak di berikan stimulasi untuk perkembangan dan pertumbuhannya tanpa dibatasi oleh jenis kelamin mereka. Artinya, baik anak laki-laki dan anak perempuan sudah seyogyanya mendapatkan kesempatan dan ruang yang sama untuk mendapatkan pendidikan yang holistik dalam meningkatkan aspek-aspek perkembangan dan pertumbuhannya secara optimal.

Namun, beberapa penelitian menemukan adanya keterbatasan akses dan ruang di PAUD yang berpotensi mengecualikan anak laki-laki dan anak perempuan karena jenis kelamin mereka (Macnaughton, 2000; MacNaughton, 2005; Ramdaeni, Adriany, Yulindrasari, 2019; Ramdaeni, Adriany, \& Yulindrasari, 2020; Ramdaeni, Adriany, \& Yulindrasari, 2018; Warin, \& Adriany, 2017; Marsh, 2000). Hal ini juga di tunjukan melalui penelitian yang sudah dilakukan sebelumnya, dimana anak laki-laki dan anak perempuan acapkali memiliki keterbatasan akses dan ruang untuk mengeksplorasi perkembangannya di taman bermain karena kuatnya binary gender dalam kategori maskulin dan feminim yang melanggengkan ketidaksetaraan terjadi di PAUD (Ramdaeni, Adriany, Yulindrasari, 2019).

Salah satu paradoks yang bertahan dalam literatur ilmiah adalah pengetahuan yang menunjukan bahwa keterampilan anak laki-laki dalam bernyanyi umumnya di laporkan kurang berkembang di bandingkan dengan anak perempuan, hal ini karena anggapan bahwa menyanyi adalah bentuk dari feminim (Welch, Saunders, Papageorgi, \& Himonides, 2012). Anggapan bahwa bernyanyi itu bergender juga membuat anak laki-laki dan anak perempuan percaya bahwa bernyanyi diperuntukan kepada anak perempuan, sehingga anak laki-laki menghindari stigma feminim. Hal ini karena maskulinitas dibangun dengan menghindari stigma femininitas (Paechter, 2007).

konstruksi gender yang acapkali diperkuat oleh maskulin dan feminim berpengaruh terhadap perkembangan seni anak laki-laki dan anak perempuan yang dianggap berbeda. Dimana penelitian-penelitian tersebut menunjukan bahwa kemampuan dan perkembangan seni anak perempuan seringkali lebih unggul dibandingkan dengan anak laki-laki, khususnya dalam ranah perkembangan seni, baik melalui bermain seni, bernyanyi, dan melukis (Gumilang, 2016; Suwoto, 2017; Ritonga, \& Sutapa, 2020). Sehingga anggapan tentang kategori bagaimana menjadi laki-laki dan perempuan dalam binary gender di PAUD seringkali membuat anak laki-laki kurang tertarik dengan aktivitas yang dianggap untuk anak perempuan "feminim", sehingga 


\section{Suci Ramdaeni}

partisipasi dan perkembangan dalam bernyanyi anak laki-laki kurang dibandingkan dengan anak perempuan (Hall, 2005).

Adapun penelitian-penelitian di Indonesia yang mengkaji bagaimana konstruksi gender berpotensi negatif terhadap terbatasnya akses anak dalam menyanyi masih sangat terbatas. Penelitian-penelitian di Indonesia umumnya mencari strategi dalam meningkatkan menyanyi tanpa melihat gender sebagai sesuatu yang penting. Hal ini karena perbedaan gender seringkali dianggap sebagai sesuatu yang alami (Smith, Alexander, \& Campbell, 2017).

Perbedaan maskulin dan feminim dianggap sebagai perbedaan yang alami, dimana guru juga membangun keyakinan sesuai diskursus gender yang dibangun oleh lingkungan sosialnya, dimana kemampuan perkembangan seni anak perempuan yang dianggap lebih unggul dari pada anak laki-laki dianggap sebagai alami (Chapman, 2016). Kurangnya pemahaman tentang gender hubungan antara dan anak, anak dan guru acapkali terus menerus melanggengkan ketidaksetaraan di PAUD (Adriany, V., \& Warin, J. (2014; Adriany, 2019; MacNaughton, 2000; MacNaughton, 2005).

Melalui perspektif post-developmentalisme penulis ingin menunjukan bagaimana konstruksi gender di Pendidikan anak usia dini yang berpotensi mengecualikan anak lakilaki dan anak perempuan. Post-developmentalisme membantu penulis untuk menganalisis bagaimana pendekatan tradisional untuk mengembangkan kurikulum di PAUD seringkali berasal dari pemahaman tentang teori perkembangan modernis tentang anak menyebabkan dominasi yang menghubungkan ketidaksetaraan gender terjadi antara anak-anak, anak-anak dan guru (MacNaughton, 1997).

Selain itu, penelitian tentang konstruksi gender dalam bernyanyi di PAUD masih sangat terbatas. Adapun penelitian yang dilakukan di Western yaitu hasil temuan dari Welch, Saunders, Papageorgi, \& Himonides, (2012) dan Hall (2005). Sedangkan di Indonesia masih belum ditemukan bagaimana konstruksi gender melalui bernyanyi melalui kacamata post-developmentalisme. Sehingga Penelitian ini diharapkan guru menjadi pengisi literatur ilmiah, guru dan orang dewasa untuk lebih sensitif gender dalam memahami anak melalui bernyanyi di PAUD.

Adapun tujuan dari penelitian ini selaras dengan tujuan SDG's untuk memastikan Pendidikan yang inklusif dan berkualitas. Serta mendukung anak laki-laki dan perempuan untuk mendapatkan akses dan ruang pendidikan secara dini yang berkualitas, setara bagi semua perempuan dan laki-laki tanpa dibatasi jenis kelamin 


\section{B. METODOLOGI PENELITIAN}

Penelitian ini menggunakan metodologi metaanalisis yang mengintegrasikan beberapa hasil hasil temuan penelitian terdahulu yang kemudian dianalisis melalui perspektif post-developmentalisme. Adapun tema yang muncul dalam penelitian ini adalah: (1) Konstruksi gender dalam bernyanyi; (2) Konstruksi gender melalui jenis lagu; (3) Konstruksi gender dalam Instrumen lagu dalam bernyanyi.

\section{RESULT AND DISCUSSION}

\section{Perspektif Post-Developmentalisme dan Gender}

Post-developmentalisme adalah sebuah perspektif yang mempertanyakan pengetahuan tentang teori perkembangan "developmentalisme" di Pendidikan di PAUD yang seringkali menjadi acuan kurikulum di Pendidikan anak usia dini. Selama Lebih dari 15 tahun peneliti-peneliti menantang wacana dominan dari teori perkembangan "developmentalisme" yang menjadi sumber satu-satunya pengetahuan yang dianggap sebagai kebenaran, yang meuniversalkan anak dari keberagaman budaya, sosial, dan gender (Walkerdine, 1993; Edwards, Blaise, \& Hammer, 2009)

Teori perkembangan "developmentalisme" percaya bahwa anak itu seringkali dianggap polos, naif, alami. Dimana tahapan perkembangan anak dalam teori perkembangan percaya bahwa tidak dapat memahami isu yang kompleks. Padahal sejak sejak usia tiga tahun anak sudah memahami isu yang kompleks (MacNaughton, 2000). Sehingga hal ini seringkali membentuk pengetahuan bahwa anak tidak berdaya dan menganggap bahwa anak belum bisa memahami isu gender di PAUD.

Polos dan alami yang di pahami ketika masa kanak-kanak bisa menjadi masalah, dimana anak perempuan dan anak laki-laki harus sesuai dengan konstruksi gender dilingkungannya berpotensi mengalami pengecualian. Dimana anak laki-laki dan anak perempuan yang tidak sesuai dengan kategori maskulin dan feminim di lingkungan sosialnya dianggap salah satu bentuk keterlambatan atau ketidaknormalan (Walkerdine, 1993; Jones, 1999).

Pengetahuan dan keyakinan yang diinformasikan melalui teori perkembangan atau atau Developmentally Appropriate Practice (DAP) seringkali menjadi standar dan norma bagaimana anak harus berprilaku dan bertindak termasuk kesesuaian dalam binary gender. Sehingga Post-developmentalisme memberi ruang atau menjadi perspektif alternatif untuk guru dan orang dewasa menolak atau menentang bahwa gender hanyalah ekspresi jenis kelamin atau gender merupakan sesuatu yang alami 
Suci Ramdaeni

"biologis. Tapi gender sesuatu yang di bangun melalui pengalaman, asal-usul sejarah, sosial dan budaya (Blaise, 2009).

Post-developmentalisme percaya bahwa gender di bangun melalui konstruk sosial, sehingga memberi ruang untuk merekonstruksi gender untuk lebih fleksibel. Dimana perspektif post-developmentalisme juga dapat membantu bidang PAUD untuk mengerti caranya anak-anak dan guru secara aktif membangun pengetahuan dikelas, mengungkap praktek, proses dan peran yang diamainkan anak-anak dalam mengkonstruksi gender (Blaise, 2009).

\section{Konstruksi Gender dalam Bernyanyi}

Penelitian abad ke-20 seringkali menunjukan bahwa perkembangan bernyanyi anak perempuan dianggap lebih unggul dalam arti lebih berprestasi pada usia dini di bandingkan dengan laki-laki, hal yang mendasari bias ini anggapan bahwa bernyanyi dianggap feminim. Dimana yang mendasar dari pernyataan itu merupakan efek sosiobudaya dari pada bawaan genetic yang menadasarinya (Welch, Saunders, Papageorgi, \& Himonides, 2012). Hal ini ditunjukan dalam penelitian Hall (2005) bagaimana anak lakilaki mengkonstruksi pemahaman gender antara anak laki-laki dan perempuan yang berbeda.

Hall: "Mengapa anak perempuan suka bernyanyi?”

Kelompok anak laki-laki: "Karena anak laki-laki tidak menyukainya"

Hall: “ Kenapa?”

Kelompok anak laki-laki: "Karena aku tidak menyukainya"

Hall : "Kenapa?"

Kelompok anak laki-laki: "Karena nanti beberapa orang akan menertawakan kamu"

Berdasarkan percakapan penelitian yang ditunjukan oleh penelitian Hall (2005) anak laki-laki menunjukan ketidaktertarikan dalam bernyanyi, karena bernyanyi disukai oleh anak perempuan. Selain itu, anak laki-laki menunjukan kekhawatiran Ketika bernyanyi maka teman-temannya akan menertawakannya. Hal ini menunjukan bahwa anak laki-laki seringkali menghindari stigma feminim, dimana bernyanyi dianggap sebagai ruang untuk anak perempuan.

Penelitian Paechter (2007) juga menunjukan bahwa anak laki-laki seringkali menghindari hal-hal yang berkaitan dengan feminitas, dimana hal ini sebagai upaya untuk 


\section{Suci Ramdaeni}

mempertahankan maskulinitas normatif disekolahnya. Hal ini karena apabila anak lakilaki dekat dengan konstruksi femininitas, mereka akan dianggap sebagai "laki-laki yang gagal" karena tidak sesuai dengan konstruksi gender di lingkungan sosialnya (Paechter, 2007; Hall, 2005).

Guru dan orang dewasa harus lebih sensitif gender untuk melihat ini sebagai sesuatu yang perlu perhatikan. Dimana penelitian diatas menunjukan bahwa anak lakilaki bukan berarti tidak memiliki kemampuan untuk bernyanyi, hanya saja mereka memahami bahwa bernyanyi adalah ruang untuk anak perempuan, sehingga anak lakilaki menghindari bernyanyi. Disinilah, bagaimana guru perlu membangun subjektivitas yang baru dengan memberikan membangun keyakinan kepada anak-anak bahwa bernyanyi tidak bergender. Guru dan orang dewasa dapat memberikan pengalaman dan dorongan yang sama kepada anak laki-laki dan anak perempuan dalam bernyanyi.

\section{Konstruksi Gender melalui Jenis Lagu}

Penelitian yang dilakukan oleh Hall (2005) menunjukan bahwa anak laki-laki menunjukan perbedaan pemilihan jenis lagi antara anak laki-laki dan anak perempuan. Hal ini ditunjukan melalui percakapan berikut:

Peneliti : Mengapa anak laki-laki bermain gitar?

Anak laki-laki: Karena mereka adalah bintang rock

Peneliti : Apakah cewe rock star?

Anak laki-laki : Tidak, perempuan hanyalah bintang pop

Berdasarkan percakapan diatas, menunjukan bahwa menyanyi membuka ruang kepada anak laki-laki, namun dengan perbedaan jenis lagu antara laki-laki dan anak perempuan. Dimana anak laki-laki percaya bahwa ruang bernyanyi perempuan hanyalah cocok untuk jenis lagu "pop".

Hal tersebut, berpotensi mengecualikan kesempatan anak laki-laki yang ingin bernyanyi pop, dan anak perempuan untuk bernyanyi rock karena kepercayaan gender yang mereka bangun di lingkungan sosialnya. Macnaughton (2000) percaya bahwa anak merupakan agen aktif yang tidak hanya dapat memperkuat konstruksi gender di lingkungan sekolahnya, namun juga melakukan resistensi. Sehingga, guru dan orang dewasa perlu sensitive gender terhadap kemungkinan anak disekolah yang melakukan resistensi gender terhadap gender tradisional di PAUD. 
Selain itu, anak juga acapkali merepresentasikan lagu dengan makna lain. Hal ini di jelaskan dalam penelitian Blaise (2009) dimana peneliti melakukan percakapan dengan tiga anak perempuan yaitu Mary, Maggie, dan Felipe.

Peneliti bertanya dikelas tentang beberapa lagu dan apakah anak-anak perempuan tersebut tahu, dan mereka tahu bahwa lagu tersebut dinyanyikan oleh Christina Aguilera. Kemudian mereka melakukan percakapan

Felipe: "dia bernyanyi tentang cara mendapatkan pacar, semua gadis ingin dan membutuhkan pacar"

Mindy: "Apakah ini benar, semuanya?"

Seluruh anak perempuan: Ya

Marry juga menambahkan bahwa dia ingin menjadi seksi seperti chistina Aguilera, Elena: "dia pintar, baik, dia memiliki rambut Panjang"

Hall (2009) menjelaskan dalam penelitian tersebut bahwa anak-anak memiliki pendapat yang kuat tentang apa artinya menjadi laki-laki dan menjadi perempuan. Hal ini di tunjukan dalam penelitian Hall, dimana anak perempuan perlu menjadi cantik, memiliki dan membutuhkan pacar. Ini juga menunjukan bahwa anak berperan aktif dalam mengkonstruksi dan merekontruksi pengetahuan tentang gender, dan seksualitas di lingkungan anak usia dini.

\section{Konstruksi gender dalam Instrumen lagu dalam bernyanyi}

Konstruksi gender juga seringkali ditunjukan melalui instrument lagu dalam bernyanyi. Hal ini ditunjukan melalui percakapan dalam penelitian Hall (2005).

Peneliti : Mengapa anak laki-laki memainkan drum?

Anak laki-laki : karena mereka berisik

Peneliti: Apakah anak perempuan menyukai hal yang berisik?

Anak Laki-laki: Tidak

Peneliti : Apa yang mereka suka?

Anak laki-laki: Suara yang manis 


\section{Suci Ramdaeni}

Dalam percakapan diatas, anak laki-laki percaya bahwa drum diperuntukan untuk anak laki-laki. Dimana "berisik" seringkali mengacu pada konstruksi maskulinitas, berbeda dengan perempuan, dimana perempuan mengacu pada sesuatu yang "manis". Hal ini juga dijelaskan oleh Chapman (2016) menjelaskan bahwa stereotipe gender tanpa sadar mengatur bagaimana interaksi sosial, ruang, dan kesempatan anak-anak secara berbeda dalam pengaturan di PAUD. Dimana Hall (2005) juga menjelaskan bahwa anak laki-laki dan perempuan seringkali memilih sesuatu yang berlawanan.

\section{CONCLUSION}

Melalui perspektif post developmentalism penelitian ini menunjukan bahwa binary gender melalui maskulin dan feminim di langgengkan di PAUD. Perbedaan maskulin dan feminim ini berpotensi negative, dimana hal ini membatasi ruang dan kesempatan anak laki-laki dan anak perempuan untuk mengeksplorasi perkembangannya. Dimana dalam bernyanyi seringkali hal ini membuka kesempatan yang terbuka kepada anak perempuan, karena bernyanyi seringkali dianggap bentuk dari "femininitas". Padahal apabila anak laki-laki diberikan stimulasi dan kesempatan dalam mengembangkan keterampilan bernyanyi secara berkelanjutan, mereka mampu menjadi lebih terampil. Hanya saja terkadang batas-batas antara masyarakat yang di konstruksi anak tentang praktek maskulin dan feminim untuk anak usia dini lebih diperkuat dengan memberikan ruang, kegiatan dan bermain di kelompok satu jenis kelamin yang sama.

\section{REFERENCES}

Adriany, V. (2019). Being a princess: young children's negotiation of femininities in a Kindergarten classroom in Indonesia. Gender and Education, 31(6), 724-741.

Adriany, V., \& Warin, J. (2014). Preschool teachers' approaches to care and gender differences within a child-centred pedagogy: findings from an Indonesian kindergarten. International Journal of Early Years Education, 22(3), 315-328

Blaise, M. (2009). "What a girl wants, what a girl needs": Responding to sex, gender, and sexuality in the early childhood classroom. Journal of Research in Childhood Education, 23(4), 450-460.

Chapman, R. (2016). A case study of gendered play in preschools: How early childhood educators' perceptions of gender influence children's play. Early Child Development and Care, 186(8), 1271-1284. 
Suci Ramdaeni

Edwards, S., Blaise, M., \& Hammer, M. (2009). Beyond developmentalism? Early childhood teachers' understandings of multiage grouping in early childhood education and care. Australasian Journal of Early Childhood, 34(4), 55-63.

Gumilang, M. S. (2016). Representasi Gender pada Seni Lukis Kreativitas Anak. JURNAL RUPA, 1(2).

Jones, O. (1999). Tomboy tales: The rural, nature and the gender of childhood. Gender, place and culture: A journal of feminist geography, 6(2), 117-136.

MacNaughton, G. (2000). Rethinking gender in early childhood education. Sage.

MacNaughton, G. (2005). Doing Foucault in early childhood studies: Applying poststructural ideas. Psychology Press.

Marsh, J. (2000). But I want to fly too!: Girls and superhero play in the infant classroom. Gender and education, 12(2), 209-220.

Paechter, C. (2007). Being boys; being girls: Learning masculinities and femininities: Learning masculinities and femininities. McGraw-Hill Education (UK).

Ramdaeni, S., Adriany, V., \& Yulindrasari, H. (2018). Gender, Power and Play in Early Childhood Education.

Ramdaeni, S., Adriany, V., \& Yulindrasari, H. (2019, September). Space and gender: Playing in early childhood education. In Early Childhood Education in the 21st Century: Proceedings of the 4th International Conference on Early Childhood Education (ICECE 2018), November 7 , 2018, Bandung, Indonesia (p. 133). Routledge.

Ramdaeni, S., Adriany, V., \& Yulindrasari, H. (2020, August). Gender and Toys in Early Childhood Education. In International Conference on Early Childhood Education and Parenting 2009 (ECEP 2019) (pp. 250-254). Atlantis Press.

Ritonga, R. A., \& Sutapa, P. (2020). Literasi dan Gender: Kesenjangan yang Terjadi di Tingkat Pendidikan Anak Usia Dini. Jurnal Obsesi: Jurnal Pendidikan Anak Usia Dini, 5(1), 965974.

Smith, K., Alexander, K., \& Campbell, S. (Eds.). (2017). Feminism (s) in early childhood: Using feminist theories in research and practice (Vol. 4). Springer.

Suwoto, A. N. (2017). Efektivitas ekstrakurikuler menari dalam meningkatkan perkembangan sosioemosi pada anak usia dini di TK Kartika V-38 Tanah Laut Kalimantan Selatan (Doctoral dissertation, Universitas Islam Negeri Maulana Malik Ibrahim).

Walkerdine, V. (1993). Beyond developmentalism?. Theory \& Psychology, 3(4), 451-469.

Warin, J., \& Adriany, V. (2017). Gender flexible pedagogy in early childhood education. Journal of gender studies, 26(4), 375-386. 
Suci Ramdaeni

Welch, G. F., Saunders, J., Papageorgi, I., \& Himonides, E. (2012). Sex, gender and singing development: Making a positive difference to boys' singing through a national programme in England. In Perspectives on males and singing (pp. 27-43). Springer, Dordrecht. 